Research Article

\title{
In Vitro Determination of Sun Protection Factor of Water Extract of Aerodramus fuciphagus from Central Kalimantan
}

Dita Ayulia Dwi Sandi 1*
Eka Fitri Susiani 10
I Ketut Adnyana 20
Pratiwi Wikaningtyas 2
1Department of Pharmacy, Sekolah
Tinggi Ilmu Kesehatan Borneo Lestari,
Banjarbaru, South Kalimantan,
Indonesia Institute of
2Department of Pharmacology-Clinical
Pharmacy, Bandung Java,
Technology, Bandung, West Java
Indonesia
*email:
ditaayulia@stikesborneolestari.ac.id
Keywords:
Aerodramus fuciphagus
Edible-nest swiftlet's Nest
Erythema transmission
Pigmentation transmission
Sun Protection Factor
Sunscreen

\begin{abstract}
Sunscreen is a cosmetic substance that has the ability to reflect or absorb sunlight actively. It can prevent skin irritation due to UV rays. One of the natural ingredients with a sunscreen effect is the Ediblenest swiftlet's (Aerodramus fuciphagus) nest (ESN). This study aimed to determine the value of the sun protective factor (SPF) of the ESN water extract. The ESN water extract solution with variation concentration, this is 2000, 2500, 5000, 6000, and 7000 ppm, were measured by spectrophotometric UV-Vis at wavelength 290-375 nm with $5 \mathrm{~nm}$ intervals to determine the value of SPF, percentage of erythema transmission $(\% \mathrm{Te})$, and percentage of pigmentation transmission (\% Tp) of ESN water extract. The result showed that the ESN water extract's SPF values at the concentration 2000, 2500, 5000, 6000, and 7000 ppm were $7.80 ; 9.68 ; 18.75 ; 20.58$; and 22.24 . The value of $\% \mathrm{Te}$ of each concentration were $15.60 \pm 0.19 ; 10.03 \pm 0.42 ; 1.24 \pm 0.04 ; 0.81 \pm 0.01$ and $0.56 \pm 0.01$. While the value of $\% \mathrm{Tp}$ of each concentration was showed the sunblock category. In conclusion, the ESN water extract from Central Kalimantan at the concentration of $6000 \mathrm{ppm}$ has potential in ultraviolet protection against the skin in the ultra category with sunblock category mechanism. Further, it can be developed into sunscreen cosmetics from natural ingredients.
\end{abstract}

Received: October $10^{\text {th }}, 2020$

Accepted: January 29th, 2021

Published: May 30th, 2021

(c) 2021 Dita Ayulia Dwi Sandi, Eka Fitri Susiani, I Ketut Adnyana, Pratiwi Wikaningtyas. Published by Institute
for Research and Community Services Universitas Muhammadiyah Palangkaraya. This is an Open Access article
under the CC-BY-SA License (http://creativecommons.org/licenses/by-sa/4.0/). DOI: https:// doi.org/10.33084/ bjop.v4i2.1782

\section{INTRODUCTION}

The effect of sunlight (UV light) on the skin will damage cells, causing wrinkles, causing skin color and texture change. The negative effect of sunlight can be reduced by using sunscreen ${ }^{1}$. Sunscreen is a cosmetic substance that has functions to reflect or absorb sunlight. It can prevent skin irritation due to UV rays². Sunscreens can absorb sunlight at a wavelength of $290-320 \mathrm{~nm}$ for UVB about $85 \%$ but can reflect sunlight at a wavelength of more than $320 \mathrm{~nm}$ for UVA ${ }^{3}$. The active ingredients of sunscreens in FDA-approved are generally inorganic and organic. The primary inorganic materials in use are zinc oxide $(\mathrm{ZnO})$ and titanium dioxide $\left(\mathrm{TiO}_{2}\right)$, but they are photostable and require much application to achieve maximum effect ${ }^{4}$. Meanwhile, benzophenone is a UVA organic material that protects against UV B and UVA. However, benzophenone is photolabile, and its oxidation can disrupt the antioxidant system 5 . Other materials of natural origin can be used; one of them is an edible bird's nest.

Edible-nest swiftlet's nest (ESN) has been used traditionally in Asia for their health benefits. Produced by swallow species (Aerodramus fuciphagus), it is commonly found in Asian countries such as Thailand, Indonesia, and Malaysia ${ }^{6}$. Indonesia is the largest ESN-producing 
country. Several regions in Indonesia, especially Sumatra and Kalimantan, have a high quality of the ESN7. Ediblenest swiftlet's nest is commonly used as an antioxidant, anti-inflammatory, and cosmetic8. Several studies showed ESN as a tonic stimulant effect and accelerate wound healing in diabetes mellitus patients ${ }^{9-11}$.

A sunscreen contains compounds that can protect the skin from the adverse effects of sunlight ${ }^{12}$. One of the sunscreen mechanisms to protect the skin from the negative effect of sunlight is to inhibit the production of free radicals caused by UV rays and prevent endogenous antioxidants ${ }^{13}$. The ESN water extract could increase the activity of the enzyme superoxide dismutase (SOD), which can neutralize free radicals ${ }^{14}$. Superoxide dismutase is an endogenous enzymatic antioxidant with a very strong effect as a body defense against free radicals ${ }^{15}$. This study aimed to determine the value of the sun protective factor (SPF) of the ESN water extract.

\section{MATERIALS AND METHODS}

\section{Materials}

Edible-nest swiftlet's nest from Central Kalimantan was determined as Aerodramus fuciphagus from Research Center for Biology, Indonesian Institute of Sciences (No. 2400/IPH.1.02/KS.02.03/VII/2019), distilled water (Bratachem), double-distilled water (Brataco), and sucrose (Merck).

\section{Methods}

Each of $250 \mathrm{~g}$ of the ESN (Figure 1) was dissolved in $7.4 \mathrm{~L}$ of double-distilled water. They were homogenized by stirring for 30 minutes and then heated for 30 minutes at $45^{\circ} \mathrm{C}$. The solution was filtered using filter paper. The filtrate was freeze-drying (lyophilization) with freeze-dry (Eyela ${ }^{\circledR}$ ) until the ESN water extract was obtained, that was $10.8 \mathrm{~g}(4.3165 \%)$.

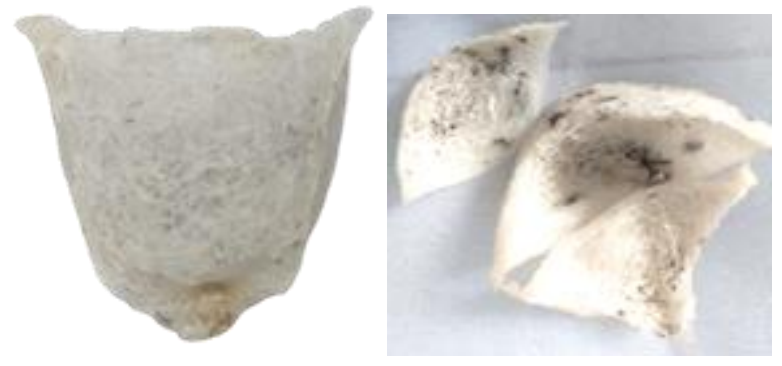

Figure 1. Edible-nest swiftlet's nest from Central Kalimantan

The ESN water extract was made at the concentration of 2000, 2500, 5000, 6000, and 7000 ppm using distilled water. The test concentration selection was based on the preliminary test results. The small concentration was used showed a very small SPF value and did not have the potential to be developed as a sunscreen, whereas if the large concentration were used would not be efficient in using research materials.

Determination of SPF value, percentage of erythema transmission $(\% \mathrm{Te})$, and percentage of pigmentation transmission (\%Tp) were measured sample absorbance using spectrophotometer UV-Vis (PG Instruments Limited() at wavelength $290-375 \mathrm{~nm}$ with interval $5 \mathrm{~nm}$. The sample absorbance was multiplied by EE x I for each interval. The value of EE $x$ I for each interval can be seen in Table I. Meanwhile, to determine the SPF value, the following Formula 1 is used:

$$
\begin{aligned}
& \qquad \mathrm{SPF}=\mathrm{CF} X \sum_{290}^{320} \mathrm{EE}(\lambda) \times \mathrm{I}(\lambda) \times \mathrm{ABS}(\lambda) \ldots[1] \\
& \mathrm{CF}=\text { Correlation Factor }(10) ; \mathrm{EE}=\text { Erythema Efficiency; I = Solar } \\
& \text { SimulationSpectrum }
\end{aligned}
$$

\begin{tabular}{cc} 
Table I. The EE $\mathbf{~ I ~ v a l u e ~ a t ~ w a v e l e n g t h ~} 290-320 \mathrm{~nm}$ \\
\hline Wavelength $/ \boldsymbol{\lambda}(\mathbf{n m})$ & $\mathbf{E E}^{*} \mathbf{x I}$ \\
\hline 290 & 0.02 \\
295 & 0.08 \\
300 & 0.29 \\
305 & 0.33 \\
310 & 0.19 \\
315 & 0.08 \\
320 & 0.02 \\
\hline Total & $\mathbf{1}$ \\
\hline
\end{tabular}

${ }^{*} \mathrm{EE}=$ erythemal effect

The \% Te and \% Tp values for each concentration of ESN water extract were determined using Formula 2, 3, and 4. 


$$
A=-\log T \ldots[2]
$$

A = absorbance; $\mathrm{T}=$ transmission value

$$
\begin{aligned}
& \%(\mathrm{Te})=\frac{\sum \mathrm{Ee}}{\sum \mathrm{Fe}}=\frac{\sum(\mathrm{T} \times \mathrm{Fe})}{\sum \mathrm{Fe}} \ldots[3] \\
& \%(\mathrm{Tp})=\frac{\sum \mathrm{Ep}}{\sum \mathrm{Fp}}=\frac{\sum(\mathrm{T} \times \mathrm{Fp})}{\sum \mathrm{Fp}} \ldots[4]
\end{aligned}
$$

$\mathrm{T}=$ Transmission

$\mathrm{Fe}=$ erythema flux at a certain wavelength

$\mathrm{Ee}=$ The amount of erythema flux that is continued by sunscreen

$\mathrm{Fp}=$ Pigmentation flux at a certain wavelength

$\mathrm{Ep}=$ The amount of pigmentation flux that sunscreen continues.

\section{RESULTS AND DISCUSSION}

Sun Protection Factor was defined as an indicator that describes a substance's effectiveness to protect skin from UV rays. This value describes a sunscreen's ability to a protective effect on the skin from UV rays ${ }^{16}$. The SPF value of ESN water extract could be seen in Table II. The concentration of 2500; 5000; 6000, and 7000 ppm of ESN water extract had the ability as sunscreen in the maximum and ultra category. The lowest concentration of ESN water extract had the ability as sunscreen in the ultra category was 5000 ppm has an SPF value of 18.75 means that the sunscreen can protect the skin for $18.7 \times 10$ minutes $=187$ minutes from the UV light. The highest concentration of ESN water extract had the ability as sunscreen in the ultra category was 7000 ppm has an SPF value of 22.24 means that the sunscreen can protect the skin for $22.2 \times 10$ minutes $=222$ minutes from the UV light. The higher concentration, the higher the SPF value

\begin{tabular}{|c|c|c|c|c|c|c|}
\hline \multirow{2}{*}{$\begin{array}{c}\lambda \\
(\mathrm{nm})\end{array}$} & \multirow{2}{*}{$\begin{array}{l}\mathrm{EE} \\
\mathrm{xI}\end{array}$} & \multicolumn{5}{|c|}{ EEx I x Absorbance (ppm) } \\
\hline & & 2000 & 2500 & 5000 & 6000 & 7000 \\
\hline \multirow{2}{*}{290} & 0.02 & $0.02 \pm$ & $0.02 \pm$ & $0.04 \pm$ & $0.04 \pm$ & $0.04 \pm$ \\
\hline & & $0.2 \times 10^{-7}$ & $3.6 \times 10^{-7}$ & $1.9 \times 10^{-7}$ & $0.5 \times 10^{-7}$ & $0.9 \times 10^{-7}$ \\
\hline \multirow[t]{2}{*}{295} & 0.08 & $0.08 \pm$ & $0.09 \pm$ & $0.18 \pm$ & $0.2 \pm$ & $0.21 \pm$ \\
\hline & & $4.5 \times 10^{-7}$ & $0.6 \times 10^{-5}$ & $4.5 \times 10^{-7}$ & $0.6 \times 10^{-6}$ & $0.2 \times 10^{-5}$ \\
\hline \multirow[t]{2}{*}{300} & 0.29 & $0.24 \pm$ & $0.30 \pm$ & $0.59 \pm$ & $0.63 \pm$ & $0.7 \pm$ \\
\hline & & $0.6 \times 10^{-5}$ & $6.1 \times 10^{-5}$ & $4.8 \times 10^{-5}$ & $0.3 \times 10^{-5}$ & $0.6 \times 10^{-5}$ \\
\hline \multirow[t]{2}{*}{305} & 0.33 & $0.25 \pm$ & $0.31 \pm$ & $0.6 \pm$ & $0.67 \pm$ & $0.72 \pm$ \\
\hline & & $0.6 \times 10^{-5}$ & $6.9 \times 10^{-5}$ & $1.6 \times 10^{-5}$ & $0.3 \times 10^{-5}$ & $0.1 \times 10^{-4}$ \\
\hline \multirow[t]{2}{*}{310} & 0.19 & $0.13 \pm$ & $0.16 \pm$ & $0.31 \pm$ & $0.35 \pm$ & $0.36 \pm$ \\
\hline & & $0.2 \times 10^{-5}$ & $0.2 \times 10^{-4}$ & $0.7 \times 10^{-6}$ & $0.6 \times 10^{-5}$ & $0.3 \times 10^{-5}$ \\
\hline \multirow[t]{2}{*}{315} & 0.08 & $0.05 \pm$ & $0.07 \pm$ & $0.13 \pm$ & $0.15 \pm$ & $0.15 \pm$ \\
\hline & & $0.3 \times 10^{-6}$ & $0.3 \times 10^{-5}$ & $1.8 \times 10^{-5}$ & $0.7 \times 10^{-6}$ & $0.9 \times 10^{-7}$ \\
\hline \multirow[t]{2}{*}{320} & 0.02 & $0.01 \pm$ & $0.01 \pm$ & $0.03 \pm$ & $0.03 \pm$ & $0.03 \pm$ \\
\hline & & $0.3 \times 10^{-7}$ & $0.9 \times 10^{-7}$ & $0.5 \times 10^{-7}$ & $0.8 \times 10^{-8}$ & $0.2 \times 10^{-7}$ \\
\hline \multicolumn{2}{|c|}{ SPF } & $7.8 \pm 0.05$ & $9.68 \pm 0.18$ & $\begin{array}{c}18.75 \pm \\
0.06\end{array}$ & $20.58 \pm$ & $22.24 \pm$ \\
\hline \multicolumn{2}{|c|}{ Ability } & Extra & Maximal & Ultra & Ultra & Ultra \\
\hline
\end{tabular}
of ESN water extract (Figure 2).

Table II. The value of SPF of ESN water extract

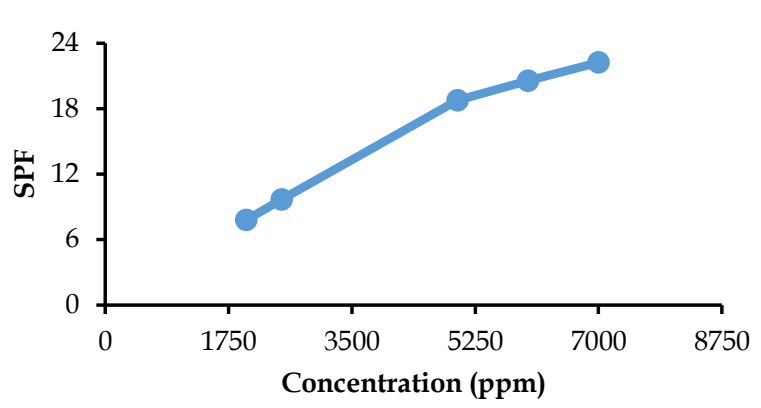

Figure 2. Sun Protection factor of the ESN water extract

The ESN contains epidermal growth factor (EGF); when binds to the epidermal growth factor receptor (EGFR), it would increase the formation of protein skeletons and activate STAT5B through translocation of the nucleus pathway to make the protein formation process occurred8,17. The protein that was formed would be hydrolyzed into peptides. Peptides consist of a series of amino acids that acted as antioxidants due to the presence of phenol groups in amino acids ${ }^{18}$. Phenol compounds had potential as sunscreens because of chromophore groups that could absorb ultraviolet, reducing their intensity on the skin ${ }^{19}$. The ESN water extract could increase the activity of the enzyme SOD, which could neutralize free radicals. Superoxide dismutase was an endogenous enzymatic antioxidant with a very strong effect as a body defense against free radicals ${ }^{20,21}$. One of the mechanisms of sunscreen to protect the skin from the harmful effects of sunlight was by absorbing UV of sunlight ${ }^{22}$.

Natural chemicals like polyphenols (flavonoids, tannins), carotenoids, anthocyanidins, few vitamins, fixed oils, volatile oils from vegetables, fruits, medicinal plant parts (leaves, flowers, fruits, berries), algae, and lichens were more effective than synthetic chemicals which were due to their long term beneficial effects especially against free radical generated skin damages along with UV-rays blocking. All of these possess strong antioxidant activity. Most of them had moisturizing and cooling (aloe vera juice, fixed oils), antimicrobial (volatile oils), wound healing and anti-inflammatory (polyphenols like 
curcumin), anticancer (tannins and resveratrol), antiaging or cell rejuvenating (anthocyanidins, carotenoids, vitamins) type of activities too ${ }^{23}$. The ESN water extract had a moisturizing and whitening effect, including wound healing, based on our previous research ${ }^{11,24}$.

The SPF values from other natural chemical like volatile oils were between 1 and 7. Peppermint oil (SPF 6.688) and tulsi oil (SPF 6.571) had the best SPF values ${ }^{25}$. One of the ingredients of animal origin was propolis extract; propolis was collected by bees from plants and then mixed with their saliva. Based on the research of Sinala and Salasa ${ }^{26}$, the ethanol extract of propolis had a minimum level of protection from UV at a concentration of 400 ppm (SPF value 2.8108) and ultra protection level at a concentration of $1800 \mathrm{ppm}$ (SPF value 16.465). The ESN water extract had an ultra protection level at a concentration of 5000 ppm (SPF value 18.75 \pm 0.06 ) (Table II).

The value of \%Te and \%Tp of ESN water extract could be seen in Table III. The value of \% Te of ESN water extract was defined as an indicator to determine erythema in skin due to the effect of UV light. While, the value of \% Tp of ESN water extract was defined as an indicator to determine the change in skin color due to the effect of UV light ${ }^{27}$.

The ESN water extract concentration of 2000 ppm had the mechanism as sunscreen in the fast tanning category, which means it had the smallest ability to absorb UV B and UV A rays. The ESN water extract concentration 2500 ppm had the mechanism as sunscreen in the sun tanning standard category, which means it could absorb at least $85 \%$ of UV B radiation and absorb a little UV A. While, the ESN water extract concentration 5000 ppm had the mechanism as sunscreen in the extra protection category, means it could protect the skin by absorbing $95 \%$ of UV B radiation so that it further protects the skin from the causes of skin erythema. The higher concentration, the lower the \% Te and \%Tp value of ESN water extract (Figure 3). The ESN water extract concentration 6000 and 7000 ppm had the mechanism as sunscreen in the sunblock category, which means it could protect the skin from UV radiation which causes erythema and pigmentation.

Table III. The value of \% Te and \% Te of ESN water extract

\begin{tabular}{cclcl}
\hline $\begin{array}{c}\text { Concentration } \\
(\mathbf{p p m})\end{array}$ & \% Te & Category & \% Tp & Category \\
\hline 2000 & $15.61 \pm$ & Fast & $34.64 \pm$ & Sunblock \\
& 0.19 & tanning & 0.25 & \\
2500 & $10.03 \pm$ & Suntan & $26.61 \pm$ & Sunblock \\
& 0.42 & standard & 0.56 & \\
5000 & $1.24 \pm$ & extra & $8.17 \pm$ & Sunblock \\
& 0.04 & protection & 0.11 & \\
6000 & $0.81 \pm$ & Sunblock & $5.6 \pm$ & Sunblock \\
& 0.01 & & 0.06 & \\
7000 & $0.56 \pm$ & Sunblock & $5.54 \pm$ & Sunblock \\
& 0.01 & & 0.01 & \\
\hline
\end{tabular}
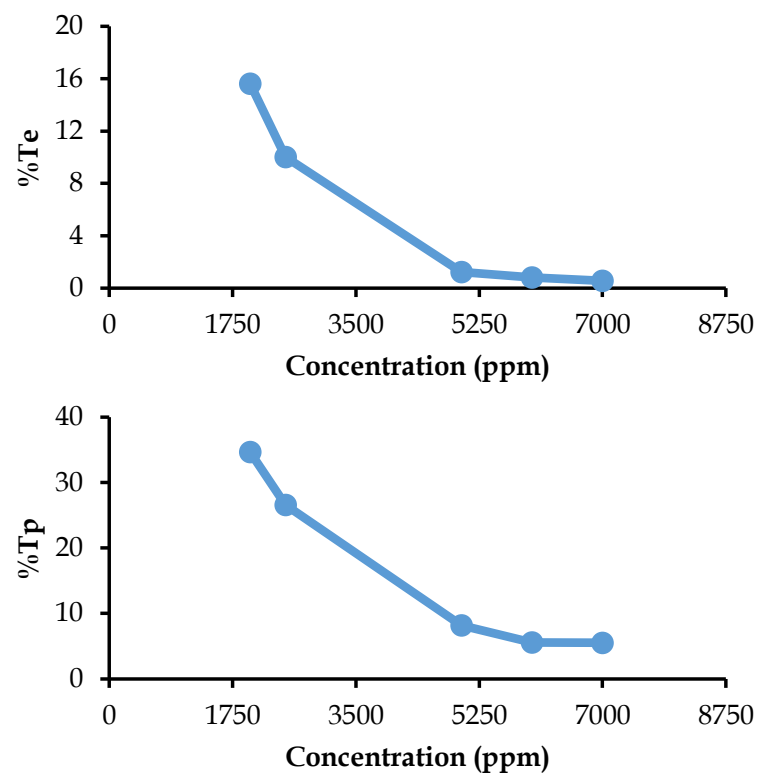

Figure 3. \% Te and \% Tp value of the ESN water extract

\section{CONCLUSION}

The ESN water extract from Central Kalimantan at the concentration 6000 ppm have potential in ultraviolet protection against the skin in the ultra category with sunblock category mechanism, and for further can be developed into sunscreen cosmetics from natural ingredients. 


\section{ACKNOWLEDGMENT}

The authors would like to thank the Ministry of Research and Higher Education of Indonesia and the entire research team. This research is collaborative research with the School of Pharmacy Bandung Institute of Technology funded by the Ministry of Research and Higher Education of Indonesia (Nu. 661/K11/KM/2019, April, 8th 2019).

\section{AUTHORS' CONTRIBUTION}

Dita Ayulia Dwi Sandi: Conceptualization, data curation, investigation, formal analysis, writing - original draft. Eka Fitri Susiani: Methodology, project administration, validation, writing - review \& editing. I

Ketut Adnyana: Supervision, Writing - review \& editing. Pratiwi Wikaningtyas: Resource, Writing - review \& editing.

\section{DATA AVAILABILITY}

All data are available from the authors.

\section{CONFLICT OF INTEREST}

There are no conflicts of interest.

\section{REFERENCES}

1. Shanbhag S, Nayak A, Narayan R, Nayak UY. Antiaging and Sunscreens: Paradigm Shift in Cosmetics. Adv Pharm Bull. 2019;9(3):348-59. doi:10.15171/apb.2019.042

2. Latha MS, Martis J, Shobha V, Shinde RS, Bangera S, Krishnankutty B, et al. Sunscreening Agents: A Review. J Clin Aesthet Dermatol. 2013;6(1):16-26.

3. Wilson BD, Moon S, Armstrong F. Comprehensive Review of Ultraviolet Radiation and the Current Status on Sunscreens. J Clin Aesthet Dermatol. 2012;5(9):18-23.
4. Sabzevari N, Qiblawi S, Norton SA, Fivenson D. Sunscreens: UV filters to protect us: Part 1: Changing regulations and choices for optimal sun protection. Int J Womens Dermatol. 2021;7(1):28-44. doi:10.1016/j.ijwd.2020.05.017

5. Rai R, Shanmuga SC, Srinivas CR. Update on Photoprotection. Indian J Dermatol. 2012;57(5):33542. doi:10.4103/0019-5154.100472

6. Hamzah Z, Ibrahim NH, Sarojini J, Hussin K, Hashim O, Lee BB. Nutritional Properties of Edible Bird Nest. J Asian Sci Res. 2013;3(6):600-7.

7. Alfianto E, Kowa KD. Rancang Bangun Rumah Budidaya Burung Walet dengan Sistem Pengendalian Suhu Otomatis Sederhana Menggunakan Arduino UNO. e-NARODROID. 2016;2(1):117-22. doi:10.31090/narodroid.v2i1.206

8. Albishtue AA, Yimer N, Zakaria MZA, Haron AW, Babji AS, Abubakar AA, et al. The role of edible bird's nest and mechanism of averting lead acetate toxicity effect on rat uterus. Vet World. 2019;12(7):1013-21. doi:10.14202/vetworld.2019.1013-1021

9. Sandi DAD, Rahmatullah SW. Pengujian Efek Tonikum Sarang Burung Walet Putih (Aerodramus fuchipagus) Pada Mencit Putih Jantan Dengan Metode Ketahanan Lama Waktu Berenang. Jurnal Pharmascience. 2016;3(2):29-35. doi:10.20527/jps.v3i2.5735

10. Sandi DAD, Rahmatullah SW. Stimulant Effect of Edible Bird's Nest (Aerodramus fuchipagus) from Borneo on White Mice. Res J Pharm Biol Chem Sci. 2018;9(3):927-30.

11. Sandi DAD, Musfirah Y. Wound Healing Effects of Edible Bird's Nests Oinment (Aerodramus fuciphagus) in Alloxan-Induced Male Rats. Majalah Obat Tradisional. 2019;24(1):33-9. doi:10.22146/mot.39072

12. Geoffrey K, Mwangi AN, Maru SM. Sunscreen products: Rationale for use, formulation development and regulatory considerations. Saudi Pharm J. 2019;27(7):1009-18. doi:10.1016/j.jsps.2019.08.003

13. Kostyuk V, Potapovich A, Albuhaydar AR, Mayer W, De Luca C, Korkina L. Natural Substances for Prevention of Skin Photoaging: Screening Systems in the Development of Sunscreen and Rejuvenation Cosmetics. Rejuvenation Res. 2018;21(2):91-101. doi:10.1089/rej.2017.1931 
14. Murugan DD, Zain ZM, Choy KW, Zamakshshari $\mathrm{NH}$, Choong MJ, Lim YM, et al. Edible Bird's Nest Protects Against Hyperglycemia-Induced Oxidative Stress and Endothelial Dysfunction. Front Pharmacol.

2019;10:1624. doi:10.3389/fphar.2019.01624

15. Younus $\mathrm{H}$. Therapeutic potentials of superoxide dismutase. Int J Health Sci. 2018;12(3):88-93.

16. D'Orazio J, Jarrett $S$, Amaro-Ortiz A, Scott T. UV Radiation and theSkin. Int JMolSci. 2013;14(6):1222248. doi:10.3390/ijms140612222

17. Roh KB, Lee J, Kim YS, Park J, Kim JH, Lee J, et al. Mechanisms of Edible Bird's Nest Extract-Induced Proliferation of Human Adipose-Derived Stem Cells. Evid Based Complement Alternat Med. 2012;2012:797520. doi:10.1155/2012/797520

18. Esfandi R, Walters ME, Tsopmo A. Antioxidant properties and potential mechanisms of hydrolyzed proteins and peptides from cereals. Heliyon. 2019;5(4):e01538. doi:10.1016/j.heliyon.2019.e01538

19. Nunes AR, Vieira IGP, Queiroz DB, Leal ALAB, Morais SM, Muniz DF, et al. Use of Flavonoids and Cinnamates, the Main Photoprotectors with Natural Origin. Adv Pharmacol Sci. 2018;2018:5341487. doi:10.1155/2018/5341487

20. Kurutas EB. The importance of antioxidants which play the role in cellular response against oxidative/nitrosative stress: current state. Nutr J. 2016;15:71. doi:10.1186/s12937-016-0186-5

21. Phaniendra A, Jestadi DB, Periyasamy L. Free Radicals: Properties, Sources, Targets, and Their Implication in Various Diseases. Indian J Clin Biochem. 2015;30(1):11-26. doi:10.1007/s12291-0140446-0

22. Paul SP. Ensuring the Safety of Sunscreens, and Their Efficacy in Preventing Skin Cancers: Challenges and Controversies for Clinicians, Formulators, and Regulators. Front Med. 2019;6:195. doi:10.3389/fmed.2019.00195

23. Donglikar MM, Deore SL. Sunscreens: A review. $\begin{array}{lll}\text { Pharmacogn } & \text { J. 2016;8(3):171-9. }\end{array}$ doi:10.5530/pj.2016.3.1

24. Sandi DAD, Susiani EF. Formulation of edible bird's nest (Aerodramus fuciphagus) from Central Kalimantan as skin whitening and moisturizing cream. J Pharm Bioallied Sci. 2021;13(1):39-45. doi:10.4103/jpbs.JPBS_276_19

25. Kaur $C D$, Saraf $S$. In vitro sun protection factor determination of herbal oils used in cosmetics. Pharmacognosy Res. 2010;2(1):22-5. doi:10.4103/0974-8490.60586

26. Sinala S, Salasa AM. Penentuan Nilai SPF (Sun Protection Factor) Dari EkstrakEtanol Propolis Secara In Vitro Untuk Penggunaan Sebagai Tabir Surya Pada Wanita. Media Kesehatan Politeknik Kesehatan Makassar. 2019;14(1):81-5. doi:10.32382/medkes.v14i1.707

27. Healy ZR, Dinkova-Kostova AT, Wehage SL, Thompson RE, Fahey JW, Talalay P. Precise determination of the erythema response of human skin to ultraviolet radiation and quantification of effects of protectors. Photodermatol Photoimmunol Photomed. 2009;25(1):45-50. doi:10.1111/j.16000781.2009.00404.x 